\title{
Thermal requirement and phenology of different cultivars of Vitis labrusca on different rootstocks
}

\author{
Exigência térmica e fenologia de diferentes cultivares de \\ Vitis labrusca sobre diferentes porta-enxertos
}

\author{
Luciane Bertoletti Barros $^{1 *}$; Gislâine Margoti²; João Guilherme Fowler; \\ Louise Larissa May De $\mathrm{Mio}^{3}$; Luiz Antonio Biasi ${ }^{3}$
}

\begin{abstract}
The knowledge of phenological stages and thermal requirement are important in vineyard management because provides information for production and quality of the grapes. This study had the objective to evaluate phenology and thermal demand of the grape cultivars Bordô, Concord, and BRS Carmem on rootstocks Paulsen 1103, IAC 766, and VR 043-43. The experiment was conducted in a family owned vineyard in Campo Largo, Paraná State, Brazil. The vineyard was carried out on ridges with semitrellis in ' $\mathrm{T}$ ' systems conducting (Geneva Double Curtain trellis). The evaluations were assessed during the production cycles of 2011/2012 and 2012/2013. The phenology was evaluated with a scale of 13 phenological stages. The thermal demand was defined by calculating the degree-days accumulation (DD) from bud swelling until harvest stage. The cultivar BRS Carmem had the longest cycle, being influenced by the rootstock, IAC 766 e Paulsen 1103 showed opposite results for cycle time. The cultivar Concord was more stable; there was no influence of rootstock on the cycle or of the thermal demand on the two harvests. The duration of the phenological cycle in 2012/2013 was lower than on the first harvest. Thermal requirement of 'BRS Carmem' was influenced by tree different rootstocks, 'Concord' was not influenced, and the results to 'Bordô' were not consistent.
\end{abstract}

Key words: Vitis labrusca, degree-day, American grapes, phenological behavior

\section{Resumo}

O conhecimento de estágios fenológicos e exigência térmica são importantes em gerenciamento de vinhedo porque providenciam informações para a produção e qualidade das uvas. Este trabalho objetivou avaliar a fenologia e exigência térmica das cultivares Bordô, Concord e BRS-Carmem sobre os porta-enxertos Paulsen-1103, IAC 766 'Campinas' e VR 043-43. O experimento foi conduzido na Região Metropolitana de Curitiba, num parreiral em propriedade de agricultura familiar, no município de Campo Largo, PR. O parreiral foi instalado em camalhões com sistema de condução em semilatada em ' $T$ '. As avaliações foram realizadas nos ciclos de produção 2011/2012 e 2012/2013. A fenologia foi avaliada por uma escala fenológica com 13 estádios. A exigência térmica foi definida pelo cálculo do acúmulo de graus-dia (GD) desde o estádio de gema inchada até a colheita. A cultivar BRS Carmen apresentou o ciclo mais longo, sendo influenciada pelo porta-enxerto, IAC 766 e Paulsen 1103 apresentaram resultados opostos para duração do ciclo. A cultivar Concord foi mais estável, não

\footnotetext{
1 Bióloga, Dra ${ }^{\mathrm{a}}$, Programa de Pós-Graduação em Agronomia, Produção Vegetal, Dept ${ }^{\circ}$ de Fitotecnia e Fitossanidade, Universidade Federal do Paraná, UFPR, Curitiba, PR, Brasil. Bolsistas da CAPES. E-mail: lubbio@gmail.com

2 Eng $^{o s}$ Agros $^{\circ}$, Discentes do Curso de Mestrado do Programa de Pós-Graduação em Agronomia, Produção Vegetal, Dept ${ }^{\circ}$ de Fitotecnia e Fitossanidade, UFPR, Curitiba, PR, Brasil. E-mail: gislainemargoti@gmail.com; joaofowler@gmail.com

3 Eng $^{\text {os }}$ Agr $^{\text {os }}$, Profs. Drs., Programa de Pós-Graduação em Agronomia, Produção Vegetal, Dept ${ }^{\circ}$ de Fitotecnia e Fitossanidade, UFPR, Curitiba, PR, Brasil. E-mail: maydemio@ufpr.br; biasi@ufpr.br

* Author for correspondence
} 
sofrendo influência do porta-enxerto sobre o ciclo e sobre a demanda térmica nas duas safras avaliadas. A duração do ciclo fenológico na safra 2012/2013 foi menor se comparada à primeira safra. A exigência térmica de BRS Carmem foi influenciada pelos diferentes porta-enxertos, Concord não apresentou esta influencia, e os resultados para cultivar Bordô não foram consistentes.

Palavras-chave: Vitis labrusca, graus-dia, uvas americanas, comportamento fenológico

\section{Introduction}

Viticulture is a traditional activity in temperate climates, but along with the current developments of grape production technology in subtropical and tropical conditions, this culture - especially of table grapes - has been under constant development in several states of Brazil, covering an area of approximately 83,700 hectares (CAMARGO et al., 2011).

The State of Paraná has extensive areas that are adequate to viticulture, but only few cultivars have been used. The cultivar Bordô is one of the most widespread because of the excellent dyeing quality (CAMARGO; MAIA, 2005); however, it is still necessary to explore the market potential and also invest in other cultivars to allow increase the harvest period. One way to verticalize grape production in the state of Paraná and provide higher value added to the farmers would be to process them into juice. There are several new American and hybrid cultivars that are getting broadly known for juice production as BRS Carmem (CAMARGO et al., 2011), however, in this region, little or no information about the characteristics of the phenology and thermal requirements of these cultivars is available.

The knowledge of phenological stages is important in vineyard management because it provides information to winemakers, as periods of higher demand for hand labor, probable cropping dates, further indicating the regional climatic potential for grape cultivation and production (RIBEIRO et al., 2010). Phenology varies according to genotype and climatic conditions of each region or from the same region due to seasonal climate throughout the year (PEDRO JÚNIOR; SENTELHAS, 2003). To understand this variation several authors assess cultivars during consecutive season and use phenological scales to compare and to establish each proper stage to cultivar (GONÇALVES et al., 2002; ANDERSON et al., 2003; MANDELLI et al., 2003; PEREIRA et al., 2008; BROETTO et al., 2011; PRADUBSUK; DAVENPORT, 2011; ANZANELLO et al., 2012). Another method to estimate the duration of the development stages of the vines is the use of thermal index or degree-days (DD). This biometeorological indicator has been studied by several authors (MURAKAMI et al., 2002; LEÃO; SILVA, 2003; SANTOS et al., 2007; CHAVARRIA et al., 2009). This two approaches used together and the study of the influence of the rootstock combination with cultivars can lead the correct strategy to decide what to plant considering harvest and susceptibility of the cultivars to different pest and diseases. Several studies were conducted in vines to verify the effect of rootstock grafted in different scion varieties for table and wine (RIBEIRO et al., 2009; MOURA et al., 2011; TOFANELLI et al., 2011), however, there are not information related to the influence of rootstock on the phenological of Bordô, Concord and BRS Carmem, in the metropolitan region of Curitiba-PR.

The objective of this study was to characterize the phenology and estimate the thermal requirement in degree days for three grape cultivars 'Concord', 'Bordô' and 'BRS Carmem' in the metropolitan region of Curitiba-PR, Brazil. A secondary objective was to detect influence of the rootstock on the phenological behavior of the scion and the thermal demand between different seasons.

\section{Material and Methods}

The experiment was realized in a field located in the Metropolitan Region of Curitiba, on a family 
owned vineyard in Campo Largo, State of Paraná, located $25^{\circ} 27^{\prime} \mathrm{S}, 49^{\circ} 31^{\prime} \mathrm{W}$, and altitude 956 $\mathrm{m}$. This region is located in a subtropical warmtemperate climate (MAACK, 1968; SOARES et al., 2002). The vineyard was deployed on a 2-m high semi trellis in ' $\mathrm{T}$ ' system (the T-bracket at the top of the post will have seven wires positioned between the two ends of the ' $\mathrm{T}$ ', connecting a post to the other, this system provides more canopy area for highly vigorous, downward growing cultivars), in 4 rows with $4.0 \times 2.5 \mathrm{~m}$ spacing. The rootstocks were planted in August 2008, and the grafting was performed the following year. The rootstocks used were Paulsen '1103', IAC 766 'Campinas' and 'VR 043-43'. The cultivars grafted were 'Bordô', 'Concord' and 'BRS Carmem'. The experiment was established in randomized blocks with 4 replications and 4 plants per plot. In the two seasons, pruning was held on August 22, leaving 4 buds per spur. The evaluations were performed in the production cycles 2011/2012 and 2012/2013 in 12 vines of each combination of cultivars Bordô, Concord and BRS Carmem grafted in Paulsen 1103, VR 043-43 and IAC 766 rootstock, totaling 108 plants which were randomly selected and tagged. On each plant were marked 2 branches, one oriented to the north and the other to the south. The vineyard was monitored every 14 days. Harvest dates were determined when the berries achieved maturity (minimum $14{ }^{\circ}$ Brix) according to the requirements of the Agriculture Ministry (BRASIL, 1974).

The phenology scale used was based on the classification of Eichorn and Lorenz (1977), with 47 grapevine phenological stages (MULLINS et al., 1994). The scale consisted of 13 phenological stages: A) Beginning of bud swelling; B) Woolly bud; C) Bud burst; D) Inflorescence emergence; E) Inflorescence fully developed; F) Beginning of flowering (10\% of flowerhoods fallen); G) Full flowering (50\% of flowerhoods fallen); H) Fruit set; I) Berries groat-sized; J) Berries pea-sized; K) Beginning of bunch compression, L) Beginning of ripening; $\mathrm{M})$ Berries ripe for harvest.
The experimental design was randomized blocks, with split plots, with 4 replications and 4 plants per plot. The plots were represented by 9 different combinations ( 3 cultivars x 3 rootstock).

The thermal requirement characterization of each cultivar and rootstock combination, this study utilized the degree-days sum (DD) since the stage A (Beginning of bud swelling) until stage M (Berries ripe for harvest). Meteorological data were obtained from the Instituto Tecnológico SIMEPAR in the Curitiba Station, and for DD calculation it was used a base temperature lower than $10{ }^{\circ} \mathrm{C}$ (MANDELLI et al., 2003; NEIS et al., 2010; PRADUBSUK; DAVENPORT, 2011; ANZANELLO et al., 2012) according to the equations proposed by Villa Nova et al. (1972):

$$
\begin{gathered}
\mathrm{DD}=\left(\mathrm{T}_{\mathrm{m}}-\mathrm{T}_{\mathrm{b}}\right)+\left(\mathrm{T}_{\mathrm{M}}-\mathrm{T}_{\mathrm{b}}\right) / 2, \text { to } \mathrm{T}_{\mathrm{m}}>\mathrm{T}_{\mathrm{b}} ; \\
\mathrm{DD}=\left(\mathrm{T}_{\mathrm{m}}-\mathrm{T}_{\mathrm{b}}\right)^{2}+2\left(\mathrm{~T}_{\mathrm{M}}-\mathrm{T}_{\mathrm{b}}\right), \text { to } \mathrm{T}_{\mathrm{m}}<\mathrm{T}_{\mathrm{b}} ; \\
\mathrm{DD}=0, \text { to } \mathrm{T}_{\mathrm{M}}<\mathrm{T}_{\mathrm{b} .}
\end{gathered}
$$

In which:

$\mathrm{DD}=$ degree-days;

$\mathrm{T}_{\mathrm{M}}=$ daily maximum temperature $\left({ }^{\circ} \mathrm{C}\right)$;

$\mathrm{T}_{\mathrm{m}}=$ daily minimum temperature $\left({ }^{\circ} \mathrm{C}\right) ; \mathrm{e}$

$\mathrm{T}_{\mathrm{b}}=$ base temperature $\left({ }^{\circ} \mathrm{C}\right)$.

Phenological data were subjected to variance analysis. The results with significant differences, from " $F$ " test outcomes, had their average subjected to Tukey's test (5\% probability significance level). Analyses were performed using the statistical software Assistat ${ }^{\circledR}$.

\section{Results and Discussion}

On both seasons, to 'BRS Carmem' with all rootstocks tested had the highest duration on the cycle to grow. The 'Bordô' and 'Concord' cultivars had rootstock influence in the 2011/2012 season. 'Concord' showed a higher cycle than 'Bordô' when grafted on IAC766 'Campinas', however, when grafted on 'VR 043-43' the opposite occurred 
(Table 1). On the season of 2012/2013 'Concord' showed a superior cycle than 'Bordô' when grafted on IAC766 'Campinas', and when grafted on 'VR 043-43', although not significantly different, the same tendency was observed in the previous cycle.

Close results of this study were observed in phenology studies: the cultivate 'Bordô', were reported days average cycle of 159 days in plants with 8 years-old in Caldas, MG, (GONÇALVES et al., 2002) and 132 days in plants with 5 years-old in Guarapuava, PR (BROETTO et al., 2011). The cultivars 'Concord' and 'Bordô', 157 days for the two cultivars, in the South of Minas Gerais (PEREIRA et al., 2008). Others studies with 'Concord' also showed similar behavior: 142-162 days in plants with 25 years-old in Fredonia, NY (ANDERSON et al., 2003), 169 days in plants with 41-42 yearsold in Prosser, WA (PRADUBSUK; DAVENPORT, 2011) and 154-167 days in plants with 16 yearsold in Eldorado do Sul, RS (ANZANELLO et al., 2012). The age of the plants did not influence the phenological behavior of cultivars, when the different experimental local possessed maximum, minimum and average temperatures close.

Table 1. The total cycle (days) duration of different combinations of grapevines cultivars and rootstocks in 2011/2012 and 2012/2013 cycle, in Campo Largo, PR, Brazil.

\begin{tabular}{|c|c|c|c|c|}
\hline & \multirow{2}{*}{ Rootstock } & \multicolumn{3}{|c|}{ Scion } \\
\hline & & BRS Carmem & Bordô & Concord \\
\hline \multirow{2}{*}{ 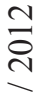 } & IAC 766 & $215 \mathrm{aA}$ & $150 \mathrm{bC}$ & $156 \mathrm{aB}$ \\
\hline & Paulsen 1103 & $206 \mathrm{bA}$ & $153 \mathrm{bB}$ & $156 \mathrm{aB}$ \\
\hline \multirow{2}{*}{$\overline{\overline{\check{\nu}}}$} & VR 043-43 & $205 \mathrm{bA}$ & $162 \mathrm{aB}$ & $153 \mathrm{aC}$ \\
\hline & $\mathrm{CV}(\%)$ & & 1.37 & \\
\hline \multirow{2}{*}{$\stackrel{m}{\stackrel{m}{\rho}}$} & IAC 766 & $163 \mathrm{cA}$ & $139 \mathrm{aB}$ & $153 \mathrm{aA}$ \\
\hline & Paulsen 1103 & $191 \mathrm{aA}$ & $139 \mathrm{aB}$ & $150 \mathrm{aB}$ \\
\hline \multirow{2}{*}{ 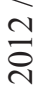 } & VR 043-43 & $176 \mathrm{bA}$ & $139 \mathrm{aB}$ & $151 \mathrm{aB}$ \\
\hline & $\mathrm{CV}(\%)$ & & 5.66 & \\
\hline
\end{tabular}

Means followed by the same lowercase letter in the column and uppercase on the line do not differ significantly by Tukey test at $5 \%$ for scion cultivars within the same cycle.

Nevertheless, on the study of the cycles from sprouting until the end of ripening for 'Bordô' and 'Concord', in Serra Gaucha, RS, it was reported 227 and 245 days, respectively (MANDELLI et al., 2003), these results were higher than those observed at the conditions of this experiment. This difference in cycle time can be explained by the fact that the plant phenology, in general, is directly influenced by environmental conditions, as temperature. The Mandelli et al. (2003) experiment was conducted in humid temperate climate, different climate from other studies cited above. This result emphasizes the importance of evaluating the phenology when you want to insert different cultivars, be scion or rootstock, in a region, knowledge of the phenological behavior is critical to the management of the vines.
In 2011/2012, the combination 'BRS Carmem'/ IAC 766 'Campinas' presented the larger cycle, 215 days, followed by 206 and 205 days for the rootstocks 'Paulsen 1103' and 'VR 043-43', respectively. For this cultivar on the 2012/2013 harvest, the combination with the rootstock IAC 766 'Campinas' showed lower average (164 days) than 'Paulsen 1103' (191 days) and 'VR 043-43' (176 days), which had lower averages comparing to the previous cycles (Table 1).

The Beginning of bud swelling (Stage A), in 2011/2012, began on September 1 for the 'Concord' cultivar and September 8 for 'Bordô' and 'BRS Carmem', with the exception of the combination 'BRS Carmem'/ 'Paulsen 1103', which started on day 22. In the 2012/2013 cultivars 'Concord' and 
'Bordô' began this phase on August 29 while 'BRS Carmem' on September 12 (Figure 1).

The Bud burst (Stage C) in 2011/2012 started later for the combination 'Bordô'/'VR 043-43', 26 days after of to start the bud swelling stage (10/04/2011) and 'BRS Carmem'/'Paulsen 1103', 23 days after Stage A (10/16/2011). All other 'Bordô' and 'Concord' combinations had averages of 13 days and 'BRS Carmem' 14 days for Bud burst, which occurred in mid-September. In the 2012/2013 crop, the beginning of the Bud burst stage (Stage C) on the combinations with 'Bordô' had the highest average, 16-19 days after Beginning of bud swelling stage, 'BRS Carmem' grafted in 'VR 043-43' the lowest (10 days) and the other started Stage C 14 days after Stage A.

The duration of Stage C, it was observed that all cultivars grafted on 'VR 043-43' had a shorter duration of this phase in the first season. However, for the second crop, this difference was not observed between the different scions and rootstocks combinations, with durations 13-22 days to Bud burst (Figure 1). Other study found a lower duration to Stage C, 5 to 6 days, varying with the rootstock in the cultivars 'Isabel' and 'Rubea' (SATO et al., 2008), however there was study the phase duration observed for 'Bordô' and 'Concord' were 28 and 23 days, respectively (MANDELLI et al., 2003).

These results showed temperature influence between seasons, and within each season there were scion and rootstock influence. Scion influence should be conditioned by photosynthesis amount that depending of the vigor of each scion, and rootstock by absorption of nutrients and water to photosynthesis, both contribute to the reserve accumulation necessary to nourish the vines, influencing duration of the dormancy period and bud burst and blossom.

The Concord cultivar presented earlier bud burst in two seasons, happening on 09/14/2011 and 09/12/2012. The 'BRS Carmem' cultivar was tardy in relation to Stage $C$, which occurred between September 22 to October 16 in 2011 and September
22 to 26 in 2012, and the 'Bordô' cultivar was intermediate, with bud burst from September 21 to October 04 in 2011 and September 14 and 172012 (Figure 1).

In the first harvest, 'BRS Carmem' grafted on 'IAC 766' e 'Paulsen 1103' showed the highest period from the stage of Inflorescence fully developed (Stage E) until the end of the stage of Fruit set (Stage $\mathrm{H}$ ), and from Stage $\mathrm{H}$ until Beginning of ripening (Stage L) than the other. In the second season, there was no difference in this period between Stage $\mathrm{E}$ and the end of Stage H, and the 'Bordô' cultivar showed a shorter period between Stage $\mathrm{H}$ and initiation of Stage L (Figure 1).

The average flowering duration (Stage $\mathrm{F}$ and G) for 'Bordô' (10-16 days) and Concord cultivars (16-19 days) obtained in this study were within the range of days found in a study in the Serra Gaúcha, RS, 'Bordô' presented 4 to 31 days and 'Concord' presented 6 to 21 days (MANDELLI et al., 2003). In the first harvest, 'BRS Carmem' showed a difference in flowering duration in all rootstocks, 28 days with 'IAC 766', 30 days with 'Paulsen 1103' and 14 days with 'VR 043-43', in the second year all had a shorter duration and 'IAC 766' (11 days) was lower than the other two rootstocks, 'Paulsen 1103' and 'VR 04343', 16 and 15 days, respectively (Figure 1).

The duration of the maturation phase (Stage L) was similar in the two seasons for the cultivars Concord (23 and 28 days) and BRS Carmem (32-35 days). However, for the cultivar Bordô, which ranged from 24 to 32 days in 2011/2012, it was reduced to just 10 to 19 days in the subsequent seasons (Figure 1). In study in Minas Gerais was reported for 'Concord' a period of 27 days (PEREIRA et al., 2008), but in the Serra Gaúcha, RS, was obtained higher values, 33 days for the Bordô and Concord cultivars (MANDELLI et al., 2003). The 'Concord' harvest occurred in early February in 2012 and the end of January in 2013. The 'Bordô' harvest occurred in early February in 2012 and mid-January in 2013. The cultivar 'BRS Carmem' had the later harvest, being harvest in April in 2012 and the end of February to March in 2013 (Figure 1). 
Figure 1. Accumulation in days of phenological stages of the cultivars Concord, Bordô and BRS Carmem, grafted on IAC 766, VR 43043, and Paulsen 1103, and total cycle (days), during seasons of 2011/2012 and 2012/2013, in Campo Largo, PR, Brazil. The numbers below the lines refer to the days of the month and the numbers above refer to the duration of phenological stages. Phenological stages: A) Beginning of bud swelling; B) Woolly bud; C) Bud burst; D) Inflorescence emergence; E) Inflorescence fully developed; F) Beginning of flowering ( $10 \%$ of flowerhoods fallen); G) Full flowering (50\% of flowerhoods fallen); H) Fruit set; I) Berries groat-sized; J) Berries pea-sized; K) Beginning of bunch compression, L) Beginning of ripening; M) Berries ripe for harvest.

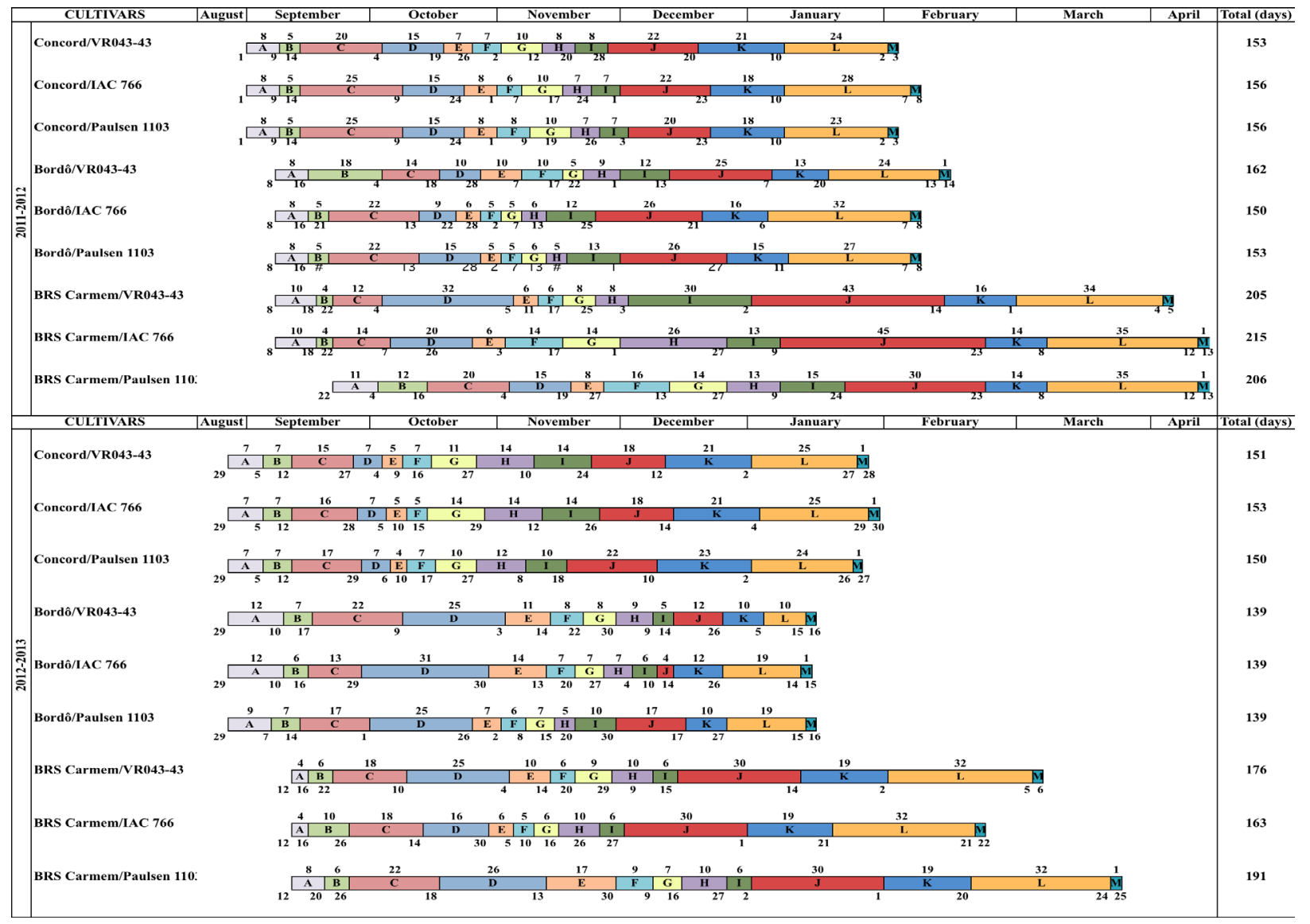

There was a significant interaction for the sum of degree-days between scion and rootstock combinations used. The 'BRS Carmem' had the highest mean of thermal requirement in the two cycles, 2186.8 on the rootstock 'IAC766' in the first season, and 2032.5 on the rootstock 'Paulsen 1103' in the second season. The lower mean of thermal demand, in the first season, was shown by 'Concord' grafted on 'Paulsen 1103' (1421.6) and 'VR043-43' (1392.6), and the second season with the 'Bordô' cultivar (Table 2) about three rootstocks. The 'Concord' cultivar was the most stable in relation to the effect of the rootstocks; there was no significant difference in the thermal demand (Table 2), or on the cycle (Table 1) at the two evaluated harvests. The average thermal sum for the 'Concord' cultivar found in this study were consistent with the values observed in study realized in Prosser, WA, in which the thermal sums were 1503 and 1414 in the years of 2006 and 2007, respectively (PRADUBSUK; DAVEPORT, 2011), and in Eldorado do Sul, RS, who reported 1554.4 to 1621.7 (ANZANELLO et al., 2012).

Both years showed in average $1.0^{\circ} \mathrm{C}$ variation in average temperature, the second cycle was higher 
than the first from August to December, and lower from January to March (Table 3). The minimum and maximum temperatures also showed similar behavior. As temperature is a limiting factor for the vine bud burst (MANDELLI, 2009), the highest temperature in the early months of the second year may have influenced the early bud burst and shortening of phenological periods. The 2011/2012 cycle was characterized by a higher volume of rainfall in August (Table 3), nonetheless this excess rain did not seem to affect the phenology for having happened during the rest period.

Table 2. Degree-days sum in 2011/2012 and 2012/2013, with base temperature lower than $10{ }^{\circ} \mathrm{C}$ for the different combinations of scion and rootstock grapevine cultivars in Campo Largo, PR, Brazil.

\begin{tabular}{|c|c|c|c|c|}
\hline & \multirow{2}{*}{ Rootstock } & \multicolumn{3}{|c|}{ Scion } \\
\hline & & BRS Carmem & Bordô & Concord \\
\hline \multirow{2}{*}{$\stackrel{\sim}{\stackrel{N}{\sim}}$} & IAC 766 & $2186.8 \mathrm{aA}$ & $1415.5 \mathrm{cB}$ & $1431.8 \mathrm{aB}$ \\
\hline & Paulsen 1103 & $2086.7 \mathrm{bA}$ & $1464.9 \mathrm{bB}$ & $1421.6 \mathrm{aC}$ \\
\hline \multirow{2}{*}{$\begin{array}{l}\overline{ } \\
\overline{\text { }}\end{array}$} & VR 043-43 & $2085.3 \mathrm{bA}$ & $1564.2 \mathrm{aB}$ & $1392.6 \mathrm{aC}$ \\
\hline & $\mathrm{CV}(\%)$ & & 1.73 & \\
\hline \multirow{2}{*}{ 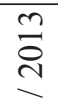 } & IAC 766 & $1699.0 \mathrm{cA}$ & $1434.0 \mathrm{aB}$ & $1619.5 \mathrm{aA}$ \\
\hline & Paulsen 1103 & $2032.5 \mathrm{aA}$ & $1432.1 \mathrm{aC}$ & $1584.0 \mathrm{aB}$ \\
\hline \multirow{2}{*}{$\frac{\grave{\sim}}{\stackrel{\sim}{\sim}}$} & VR 043-43 & $1866.8 \mathrm{bA}$ & $1434.3 \mathrm{aC}$ & $1594.1 \mathrm{aB}$ \\
\hline & $\mathrm{CV}(\%)$ & & 6.36 & \\
\hline
\end{tabular}

Means followed by the same lowercase letter in the column and uppercase on the line do not differ significantly by Tukey test at $5 \%$ for scion cultivars within the same cycle.

Table 3. Mean temperature $\left({ }^{\circ} \mathrm{C}\right)$, total precipitation (mm), mean relative humidity (MRH) (\%) monthly in $2011 / 2012$ and 2012/2013, in Campo Largo, PR, Brazil.

\begin{tabular}{|c|c|c|c|c|c|c|}
\hline \multirow{2}{*}{ Month } & \multicolumn{2}{|c|}{ Mean temperature $\left({ }^{\circ} \mathrm{C}\right)$} & \multicolumn{2}{|c|}{ Total precipitation (mm) } & \multicolumn{2}{|c|}{ MRH (\%) } \\
\hline & $2011 / 2012$ & $2012 / 2013$ & $2011 / 2012$ & $2012 / 2013$ & $2011 / 2012$ & $2012 / 2013$ \\
\hline August & 14.6 & 16.2 & 231.0 & 31.2 & 77.3 & 80.1 \\
\hline September & 14.8 & 16.8 & 61.4 & 60.0 & 78.5 & 80.7 \\
\hline October & 17.3 & 19.0 & 197.4 & 162.4 & 80.4 & 79.8 \\
\hline November & 17.6 & 18.9 & 88.2 & 53.2 & 79.0 & 82.0 \\
\hline December & 19.7 & 22.3 & 123.2 & 248.6 & 79.6 & 80.8 \\
\hline January & 20.1 & 19.8 & 114.2 & 71.4 & 78.8 & 80.5 \\
\hline February & 22.0 & 21.0 & 199.6 & 189.6 & 80.7 & 80.7 \\
\hline March & 20.5 & 19.3 & 46.0 & 125.0 & 77.2 & 78.4 \\
\hline
\end{tabular}

Using the knowledge of the phenology and thermal requirement generated in this study, some cultural practices can be programmed in the viticulture. The behavior of the cultivars can be used as a strategy to produce grape juice during longer periods than used by the growers, because the harvest of 'Concord' or 'Bordô' began in January to February and 'BRS Carmem' of February to April. Thus there is the possibility to harvest grapes to the industry from January to April. This expanding of the harvest period added to the quality of these cultivars to produce juice and rusticity (CAMARGO et al., 2011), qualitative assignments that are being discovered for the grape juice, as presence of the phenolic compounds and antioxidants (Eichorn and Lorenz 1977, MACHADO et al., 2011) and increased sales of this processed, provide a great economic benefit to farms in the region. 


\section{Conclusions}

The characterization demonstrated that 'BRS Carmem' had the largest thermal requirement, and 'Concord' and 'Bordô' had shorter than 'BRS Carmem', so at metropolitan region of Curitiba can be recommended to plant 'Concord' or 'Bordô' and 'BRS Carmem' to have grapes for juice industry harvested from January to April.

Thermal requirement of 'BRS Carmem' was influenced by tree different rootstocks, 'Concord' was not influenced, and the results to 'Bordô' were not consistent.

\section{Acknowledgment}

We thank CNPq for funding to this project; CAPES for research support through doctorate scholarship and Mr. Valmir Gogola for providing a part of his land for the experiments.

\section{References}

ANDERSON, L. J.; COMAS, L. H.; LAKSO, A. N.; EISSENSTAT, D. M. Multiple risk factors in root survivorship: a 4-year study in Concord grape. New Phytologist, Lancaster, v. 158, n. 3, p. 489501, 2003. Available at: <http://dx.doi.org/10.1046 /j.1469-8137.2003.00757.x>. Acesso em: 26 mar. 2014.

ANZANELLO, R.; SOUZA, P. V. D.; COELHO, P. F. Fenologia, exigência térmica e produtividade de videiras 'Niagara Branca', 'Niagara Rosada' e 'Concord' submetidas a duas safras por ciclo vegetativo. Revista Brasileira de Fruticultura, Jaboticabal, v. 34, n. 2, p. 366376, 2012. Disponível em: <http://dx.doi.org/10.1590/ S0100-29452012000200008>. Acesso em: 26 mar. 2014.

BRASIL. Ministério da Agricultura. Complementação de padrões de identidade e qualidade para suco, refresco e refrigerante de uva. Secretaria Nacional de Defesa Agropecuária. Secretaria de Inspeção de Produtos Vegetais. Brasília. 1974. 29 p.

BROETTO, D.; BAUMANN JUNIOR, O.; SATO, A. J.; BOTELHO, R. V. Desenvolvimento e ocorrência de Pérola-da-Terra em videiras rústicas e finas enxertadas sobre os porta-enxertos VR 043-43 e Paulsen 1103. Revista Brasileira de Fruticultura, Jaboticabal, v. 33, p. 404-410,
2011. Número Especia1 1. Disponível em: $<$ http://dx.doi. org/10.1590/S0100-29452011000500052>. Acesso em: 26 mar. 2014.

CAMARGO, U. A.; MAIA, J. D. G. Sistema de produção de uvas rústicas para processamento em regiões tropicais do Brasil. Bento Gonçalves: EMBRAPA-CNPUV, 2005. Disponível em: <http://www.cnpuv.embrapa.br/publica/ sprod/UvasRusticasParaProcessamento/cultivares.htm>. Acesso em: 31 mar. 2014.

CAMARGO, U. A.; TONIETTO, J.; HOFFMANN, A. Progressos na viticultura brasileira. 2011. Revista Brasileira de Fruticultura, Jaboticabal, v. 33, p. 144-149, 2011. Número Especia1 1. Disponível em: $<\mathrm{http} / / / \mathrm{dx}$.doi. org/10.1590/S0100-29452011000500017>. Acesso em: 26 mar. 2014.

CHAVARRIA, G.; SANTOS, H. P. dos; MANDELLI, F.; MARODIN, G.; BERGAMASCHI, H.; CARDOSO, L. S. Caracterização fenológica e requerimento térmico da cultivar Moscato Giallo sob cobertura plástica. Revista Brasileira de Fruticultura, Jaboticabal, v. 31, n. 1, p. 119126, 2009. Disponível em: <http://dx.doi.org/10.1590/ S0100-29452009000100018>. Acesso em: 26 mar. 2014.

DANI, C.; OLIBONI, L. S.; BONATTO, D.; VANDERLINDE, R.; SALVADOR, M.; HENRIQUES, J. A. P. Phenolic content and antioxidant activities of white and purple juices manufactured with organicallyor conventionally-produced grapes. Food Chemical Toxicology, Boston, v. 45, n. 12, p. 2574-2580, 2007.

EICHORN, K. W.; LORENZ, H. Phaenologische entwicklungstadien der rebe. Nachrichtenblatt des Deutschen Pflanzenschutzdienstes, Braunschweig, v. 29, n. 1, p. $119-120,1997$.

GONÇALVES, C. A. A.; LIMA, L. C. O.; CHALFUN, N. N. J.; REGINA, M. A.; ALVARENGA, A. A.; SOUZA, M. T. Fenologia e qualidade do mosto de videiras 'Folha de figo' sobre diferentes porta-enxertos, em Caldas, sul de Minas Gerais. Ciência e Agrotecnologia, Lavras, v. 26, n. 6, p. 1178-1184, 2002. <http://hortibrasil.org.br/ jnw/images/stories/Uva/u.62.pdf.>. Acesso em: 02 jun. 2014.

LEÃO, P. C. da S.; SILVA, E. E. G. Caracterização fenológica e requerimentos térmicos de variedades de uvas sem sementes no Vale do São Francisco. Revista Brasileira de Fruticultura, Jaboticabal, v. 25, n. 3, p. 379382, 2003. Disponível em: <http://dx.doi.org/10.1590/ S0100-29452003000300004>. Acesso em: 26 mar. 2014.

MAACK, R. Geografia fisica do Estado do Paraná. Curitiba: Banco de Desenvolvimento do Paraná, 1968, $350 \mathrm{p}$. 
MACHADO, M. M.; MONTAGNER, G. F. F. S.; BOLIGON, A.; ATHAYDE, M. L.; ROCHA, M. I. U. M.; LERA, J. P. B.; BELLÓ, C.; CRUZ, I. B. M. Determination of polyphenol contents and antioxidant capacity of non-alcoholic red grape products (Vitis labrusca) from conventional and organic crops. Química Nova, São Paulo, v. 34, n. 5, p. 798-803, 2011.

MANDELLI, F. Comportamento meteorológico e sua influência na vindima de 2009 na Serra Gaúcha. Bento Gonçalves: EMBRAPA-CNPUV, 2009. (Embrapa Uva e Vinho. Documentos, 96). Disponível em: $<$ http://www. cnpuv.embrapa.br/publica/comunicado/cot096.pdf $>$. Acesso em: 31 mar. 2014.

MANDELLI, F.; BERLATO, M. A.; TONIETTO, J.; BERGAMASCHI, J.; BERGAMASCH, H. Fenologia da videira na Serra Gaúcha. Pesquisa Agropecuária Gaúcha, Porto Alegre, v. 9, n. 1-2, p. 129-144, 2003.

MOURA, F. M.; TECCHIO, M. A.; HERNANDES, J. L.; MOURA, N. F.; SELEGUINI, A. Comportamento produtivo da videira, cultivar Juliana, sobre três portaenxertos em diferentes épocas de poda. Revista Brasileira de Fruticultura, Jaboticabal, p. 625-631, 2011. Volume Especial, Disponível em: <http://www.scielo.br/pdf/rbf/ v33nspe1/a86v33nspe1.pdf > . Acesso em: 01 abr. 2014.

MULLINS, M. G.; BOUQUET, A.; WILLIAMS, L. E. Biology of the grapevine. New York: University of Cambridge, 1994. 239 p.

MURAKAMI, K. R. N.; CARVALHO, A. J. C.; CEREJA, B. S.; BARROS, J. C. S. M.; MARINHO, C. S. Caracterização fenológica da videira cv. Itália (Vitis vinifera L.) sob diferentes épocas de poda na região norte do Estado do Rio de Janeiro. Revista Brasileira de Fruticultura, Jaboticabal, v. 24, n. 3, p. 615-617, 2002. Disponível em: <http://dx.doi.org/10.1590/S0100$29452002000300008>$. Acesso em: 26 mar. 2014.

NEIS, S.; SANTOS, S. C.; ASSIS, K. C. E.; MARIANO, Z. F. Caracterização fenológica e requerimento térmico para a videira 'Niagara Rosada' em diferentes épocas de poda no Sudoeste Goiano. Revista Brasileira de Fruticultura, Jaboticabal, v. 32, n. 3, p. 931-937, 2010. Disponível em: <http://www.scielo.br/pdf/rbf/ v24n3/15092>. Acesso em 06 fev. 2015.

PEDRO JÚNIOR, M. S.; SENTELHAS, P. C. Clima e produção. In: POMMER, C. V. (Ed.). Uva: tecnologia de produção, pós-colheita, mercado. Porto Alegre: Cinco Continentes, 2003. p. 63-107.
PEREIRA, G. E.; LIMA, L. C. O.; REGINA, M. A.; ROSIER, J. P.; FERRAZ, V.; MOURÃO UNIOR, M. Avaliação do potencial de cinco cultivares americanas para sucos de uva no sul de Minas Gerais. Ciência e Agrotecnologia, Lavras, v. 32, n. 5, p. 1531-1537, 2008. Disponível em: $<\mathrm{http}: / / \mathrm{dx}$.doi.org/10.1590/S141370542008000500026>. Acesso em: 26 mar. 2014.

PRADUBSUK, S.; DAVENPORT, J. R. Seasonal distribution of micronutrients in mature 'Concord' grape: boron, iron, manganese, copper, and zinc. Journal of the American Society for Horticultural Science, Alexandria, v. 136, n. 1, p. 69-77, 2011. Disponível em: <http:// journal.ashspublications.org/content/136/1/69. full. pdf + html $>$. Acesso em: 26 mar. 2014.

RIBEIRO, D. P.; CORSATO, C. E.; FRANCO, A. A. N.; LEMOS, J.P.; PIMENTEL, R. M.A. Fenologia e exigência térmica da videira 'Benitaka' cultivada no norte de Minas Gerais. Revista Brasileira de Fruticultura, Jaboticabal, v. 32, n. 1, p. 296-302, 2010. Disponível em: <http://dx.doi. org/10.1590/S0100-29452010005000028>. Acesso em: 10 dez. 2013.

RIBEIRO, D. R.; CORSATO, C. E.; LEMOS, J. P.; SCARPARE FILHO, J. A. Desenvolvimento e exigência térmica da videira 'Niagara Rosada', cul- tivada no Norte de Minas Gerais. Revista Brasileira de Fruticultura, Jaboticabal, v. 31, n. 3, p. 890-895, 2009. Disponível em: $<$ http://www.scielo.br/pdf/rbf/v31n3/a36v31n3.pdf $>$. Acesso em: 01 abr. 2013.

SANTOS, C. E.; ROBERTO, S. R.; SATO, A. J.; JUBILEU, B. S. Caracterização da fenologia e da demanda térmica das videiras 'Cabernet Sauvignon' e 'Tannat' para a região norte do Paraná. Acta Scientiarum, Maringá, v. 29, n. 3, p. 361-366, 2007. Disponível em: $<$ http://dx.doi.org/10.4025/actasciagron.v29i3.288>. Acesso em: 10 dez. 2013.

SATO, A. J.; SILVA, B. J.; SANTOS, C. E.; BERTOLUCCI, R.; SANTOS, R.; CARIELO, M.; GUIRAUD, M. C.; FONSECA, I. C. B.; ROBERTO, S. R. Fenologia e demanda térmica das videiras 'Isabel' e 'Rubea' sobre diferentes porta-enxertos na região norte do Paraná. Semina: Ciências Agrárias, Londrina, v. 29, n. 2, p. 283-292, 2008. Disponível em: <http://dx.doi. org/10.5433/1679-0359.2008v29n2p283>. Acesso em: 26 mar. 2014.

SOARES, P. C.; SOARES, A. P.; FIORI, A. P. Raciocínio probabilístico aplicado à suscetibilidade de escorregamentos: um estudo de caso em Campo Largo, Paraná, Brasil. Curitiba: Editora UFPR, 2002. p. 59-76. (Boletim Paranaense de Geociências, n. 50). Disponível em: <http://ojs.c3sl.ufpr.br/ojs/index.php/geociencias/ article/view/4171/3368>. Acesso em: 30 jan. 2015. 
TOFANELli, M. B. D.; BOTElHO, R. V.; PIRES, E. VILlA NOVA, N. A.; PEDRO JÚNIOR, M. J.; J. P.; VILELA, L. A. F.; RIBEIRO, D. O. Pheho- logy PEREIRA, A. R.; OMETTO, J. C. Estimativas de of "Niagara Rosada" grapevines grafted on different rootstocks grown on Cerrado (Brazilian savanna) of Goiás State, Brazil. African Journal of Biotechnology, Bowie, v. 10, n. 17, p. 3387-3392, 2011. Available at: <http://www. ajol.info/index.php/ajb/article/view/93407/82817>. Accessed at: 1 abr. 2014. graus-dias acumulados acima de qualquer temperaturabase, em função das temperaturas máxima e mínima. São Paulo: Universidade de São Paulo - Instituto de Geografia, São Paulo, 1972. 8 p. (Caderno de Ciências da Terra, 30). 